\title{
SOME QUESTIONS RELATING TO THE MEASURE OF DAMAGES IN STREET OPENING PRO- CEEDINGS IN NEW YORK CITY.
}

The statutory proceedings for acquiring private property for street purposes in New York City have given rise to a number of interesting theories as to the proper method of ascertaining the damages.

The city never becomes the owner in fee simple aisolute by proceedings to acquire land for streets. It acquires merely a limited fee for street purposes subject to the easements in the abutting owners. ${ }^{1}$ The city's title is not corporate or municipal property, but is held by it in trust for the public use of all the people of the State, and is under the unqualified control of the Legislature. ${ }^{2}$

Section $95^{6}$ of the Consolidation Act as amended by the laws of $\mathrm{r} 893$ states that the city's title is "In trust, nevertheless, that the same be appropriated and kept open for and as part of a public street, avenue, square, park or place forever in like manner as the other public streets, avenues, squares and places in the said city are and of right ought to be."

The damages awarded for land taken and the costs of the proceeding are generally paid by assessments upon the property deemed to be benefited. These awards and assessments are determined by three commissioners appointed in the proceeding by the Supreme Court. The statute directs that "compensation and recompense" shall be made to the owners whose land is taken, and that the commissioners shall ascertain "the loss and damage" caused by the taking, and the "benefit and advantage" to the land remaining after the taking. ${ }^{3}$

It should be noticed that the statute in every cosse speaks of "compensation and recompense" for the "loss and damage" to the "owners."

Whenever these sections have been before the courts for construction it has been held in every instance that the measure of

\footnotetext{
1 Story against the New York Elevated Railroad Company, go N. Y. I55556.

2 People v. Kerr, 27 N. Y. 188.

3 Consolidation Act, $\S \S 963,970,978$.
} 
compensation to be awarded to the claimant is, where his interest in the whole of the parcel of land owned by him is taken, its market value; and where his interest in a part of his land is taken and his interest in a part is left, the difference between the market value of his interest in the whole parcel before the taking and the market value of his interest in the part remaining after the taiking, disregarding, however, any benefit to the part remaining by reason of the proposed improvement.

Judge Dillon, in his work on Municipal Corporations, Section 624, discussing the rule as to the measure of damages in proceedings to take private property for public uses, referring to the property owner, says: "He is entitled to the fair and full market or pecuniary value of the property at the time it.is appropriated and no more. This statement of the rule excludes from consideration all such elements as that the owner does not desire to sell, or that the property is endeared to him by association, and the like. *** The amount to which the owner is entitled is not simply the value of the property at forced sale, but such sum as the property is worth in the market, if persons desiring to purchase were found who were willing to pay its just and full value, and no more."

In the Matter of the New York, West Shore and Buffalo Railway Company (35 Hun. 633) the court in opinion said:

"In the opinion of the Legislature full payment, at the market value of the property taken, answers the constitutional provision requiring a just compensation to be paid to the owner of property taken for the public use. The courts have uniformly concurred in such construction and uphold the validity of statutes limiting damages to the market value of the estate seized."

The rule as to the measure of damages is comparatively simple when the whole of a claimant's parcel of land is taken, and even where part only of his land is taken and part left the problem would not be such a difficult one if the commissioners were obliged to report only the excess of damage over benefit, or benefit over damage, as was once the practice in these proceed. ings; but in 1839 a statute was passed requiring "commissioners in all cases to report fully and separately to the court the amount of loss and damage and of benefit and advantage to each and every owner," etc. ${ }^{4}$ This presents many difficulties. On the one hand commissioners must avoid paying for damages that are not suffered. On the other hand they must avoid offsetting any of the benefits of the improvement in making their estimate 
of damage, as there is to be an assessment for benefit, and the owner of property partly taken and partly left must not be obliged to pay twice for the improvement-once in having a part of the benefit offset against his damage, and, in addition to that, an assessment for the same benefit that has been already charged to him. There is involved a good deal of abstract reasoning. In practice the damage and benefit are coincident, and in many cases, as where a street is widened a few feet, to separate damage to the whole parcel and benefit to the part remaining involves supposing what has never existed in fact.

Real estate experts through being asked on cross-examination their reasons for their opinions are accustomed to apply rules more or less inflexible, and express their opinions of the amount of damage in given cases to the fractional part of a cent. But while it may be necessary that they should adopt certain rules to govern their estimates in most of the cases, only to be modified where some unusual element caused by the peculiar shape or situation of the property or the uses to which it may be applied should be taken into account, the bare fact that they can thus appear to be consistent in their answers is not enough to justify their rules, unless the rules themselves can be shown to be fairly deduced from observed facts.

Owing to the fact that the courts do not set aside the reports of commissioners on account of the introduction of immaterial, irrelevant or incompetent evidence, there is a paucity of judicial decisions which indicate the correct rules to follow.

Perhaps one of the most far-reaching and important errors into which commissions have been led is that involved in adopting the so-called Hoffman rule, ${ }^{5}$ and it is very necessary for a clear idea of the assessment of damages in street-opening proceedings that this rule and the principle upon which it is based should be clearly understood. The general principle upon which it is based is that the value of all land is to be estimated with reference to some strip of land upon which it is to be deemed as having a front, and that land near the front is more valuable than land in the same parcel lying further from the front if it is to be valued with reference to the same frontage. It was formulated for the purpose of adjusting the interests of two owners, one owning the front and one the rear of a standard city lot, 25 by roo feet, their ownership being in fee simple absolute, upon uniting the two parts in one ownership.

5 The Hoffman rule is explained by Murray Hoffman in his-work on the laws relating to the City and County of New York, Vol. 2, p. 844 . 
Thus, it appears that if we take the value of the whole parcel of 25 by 100 feet as $\$ r, \infty 00$, then that portion of the lot within to feet of the street line, being 25 feet front by ro feet deep, is worth 160 , or 16 per cent of the whole; that portion of the lot within 25 feet of the street line, being 25 feet front by 25 feet deep, is worth $\$ 375$, or $37 \frac{1}{2}$ per cent of the whole; the half of the lot nearest the street, being 25 feet front by 50 feet deep, is worth $\$ 670$, or 67 per cent of the whole; that portion of the lot lying more than 75 feet from the street line, being the rear, 25 by 25 feet, is worth $\$ 125$, or $12 \frac{1}{2}$ per cent of the whole, and that portion of the lot lying more than 90 feet from the street line, being 25 by ro deep is worth but $\$ 40$, or 4 per cent of the whole.

The attempt has persistently been made by claimants to awards in proceedings to widen streets to show that the Hoffman rule was applicable in their cases, and that they were entitled to front values, calculated according to the Hoffman rule, where the fronts of their lots were taken; for instance, if a street was to be widened ro feet, a lot originally 25 by roo feet on the old street, which would be reduced to a lot 25 by 90 feet on the new street, was to be deemed as damaged 16 per cent of the value of the whole lot by reason of the taking of this strip of ro feet from the front.

They contend that the general rule of the measure of damage, as so often laid down by the courts, namely, the difference between the value of the whole before the taking and the value of the part remaining after the taking, disregarding the benefit caused by the improvement, is only to be called in for the purpose of estimating those damages over and above the value, spoken of as consequential damages, and that the owner of land taken for a public improvement is entitled first and always to the full value of the land taken, disregarding entirely its connection with any other land and the purpose for which it is taken, and that his land not taken is to be assessed for benefit, and, he having been paid his damages on the theory that the part of his lot remaining has been deprived of its old front, the part remaining can be assessed in accordance with the same theory the amount which its owner should pay in view of its receiving a new front.

The answer to this contention is, in the first place, that even though the rule may be a proper one to use for the purpose for which it was originally framed, that purpose was to adjust the interests of two owners in fee simple absolute in the case where the owner of the front land stood between the owner of the rear 
land and any means of access to his lot, and the two parts are to be united into one ownership, and that this is not the condition of affairs upon the taking of a front strip for street purposes, because the city does not take the fee simple absolute, shutting off the original owner of the whole parcel from any front at all on the new proposed street, but takes in the land a qualified fee in trust to maintain the same as a public street, subject to the easements of right of way, light and air in favor of the owner of the abutting property and of the whole public, and that at no time is that portion of the lot remaining, after the taking of such strip for the purposes of a street, deprived of a front, and that, consequently, damages should not be assessed on the theory that such lot has been deprived of a front.

Furthermore, it must be always remembered that when part of a parcel of land is taken, the question before the commissioners is not the value of the land, but the market value of the owner's interest in the land, and the damage caused to that interest by reducing the size of his plot.

The statute does not say he is entitled to the value of his land taken, considering it as separated entirely from the part remaining; in other words, what it would be worth if the title to it were vested in a separate owner and unconnected with the part remaining. The statute says he is to receive compensation and recompense for the damages which his property rights suffer.

In former times the public did not take even a qualified fee, but only an easement, for the street purposes, and this is still the case in the country, and, I believe, in many of the cities of New York State. The public in such case is called upon to pay to the persons who are deprived of their rights in the property only damages; it does not pay for the property; it gives compensation and recompense for the damages caused by the taking of the rights in the property which it must take for the public purpose.

But we have a direct and controlling judicial decision upon the application of the Hoffman rule in such a way as has been above described, namely, in the Matter of Opening College Place, decided by Judge Beach at the Special Term of the Supreme Court in April, r894. This was a most important proceeding, involving more than $\$ \mathrm{x}, 500,000$ in awards.

College place was widened on its west side 25 feet; the east side of the old street was not disturbed. The commissioners presented their report to the court, in the first instance having made up their awards and assessments in accordance with the 
Hoffman rule, as above described. As they gave awards on the theory that they took front property, and that the parcels remaining were deprived of a frontage, they laid their assessments on the same theory and assumed that the parcels remaining gained by the improvement a new frontage on a wider and extended thoroughifare, which caused the assessments on the west side, where the parcels were deemed to get the benefit of an entirely new front, to be much greater than the assessments on the east side, where the benefit was only the widened street. Judge Lawrence, before whom the report was presented for confirmation, declined to confirm it, on the ground that an erroneous principle must have been adopted by the commissioners which would lead to their making such a difference between the assessments imposed on the property on the east side and the property situated on the west side of College place.

The report then went back to the commissioners for correction, and they continued to apply the Hoffman rule, but in the opposite way; instead of considering the parcels remaining to be deprived of a frontage by reason of the taking of the front part of the lots for the widened street, they considered that the parts remaining still retained their frontage, and that the measure of damage was the difference between the value of the College place lot before the improvement and the value of a lot on College place of the size of the parcel left after the improvement, making the comparison between lots fronting on the same thoroughfare in order to avoid taking into consideration the benefit from the new widened thoroughfare. Thus the owner of a roofoot lot, 25 feet of which was taken, instead of getting $37 \frac{1}{2}$ per cent of the whole value of his roo-foot lot as damages, on the theory that he was deprived of a front, received but $12 \frac{1}{2}$ per cent of the value of his original roo-foot lot, on the theory that he was not deprived of a front, and his parcels remaining, instead of being assessed more than the lot across the street, on the theory that it was given a new front, was assessed the same amount as the lot across the street, on the theory that the benefit of the improvement was the same in both cases; namely, such benefit as comes from a widened street in place of a narrow street.

When the report thus corrected was again presented to the court for confirmation, it was duly confirmed. Judge Beach, in his opinion, after stating that the assessments on the east and west sides of the street had been equalized to conform with the suggestions contained in the opinion of the court, said: "In 
changing the principle of assessment after the first report was returned for revision they necessarily changed the awards.

* * The present report seems founded upon the principle that the damage to any lot is the difference in value between it as it now is and the value of what remains after the improvement, exclusive of any increase in value therefrom, and the benefit is the enhanced value of the decreased lot, because of its fronting upon a street of increased width with an outlet instead of upon a narrow street without an outlet. I think this rule is correct.".

Although a large amount of money was involved in this proceeding no appeal was taken from the decision of the court as thus expressed.

The same question presented in the College place widening case was presented to the General Term in the Matter of Widening Riverside Avenue, ${ }^{6}$ and decided the same way.

It will be noticed that the net results in the two reports in the College place proceeding are practically the same. To most of the owners it made no difference which theory was adopted. The reduced assessment in the second report was offset by an equally reduced award. But in many cases where streets situated in the upper portion of the city are opened through large unimproved tracts, it makes a very great difference. Commissioners are not permitted to assess property for benefit more than one-half its value as found by the Tax Commissioners for purposes of taxation; 7 and in the case of unimproved property the Tax Commissioners place the so-called tax value usually at about 25 but sometimes as low as ro per cent of its actual value. Consequently, it is often a difficult task to lay an assessment for benefit where the awards are made on a vastly different valuation of property from that which limits the amount of the assessment, without enlarging the area of assessment to the point of doing gross injustice, and hence the theory which gives the lowest award is very much in the interest of those who pay the costs.

That the claimant is to be paid for only the daniage which is suffered is shown in another line of cases, where the claimant's rights in the property are encumbered or restricted.

It is frequently the case that the rights of the owner of the fee in a piece of property which, if unencumbered, would be worth a large sum of money, are of hardly more than nominal value because of some encumbrance or restriction. As Judge

\footnotetext{
664 State Rep. 366.
}

7 Cons. Act, Sec. 975 . 
Magruder said in an Illinois case ${ }^{8}$ "where the owner of land is restricted by the statute or by the provisions of the instrument under which he holds his title, or in any other binding way, to a particular use of it so that he cannot lawfully apply it to any other use, the measure of his compensation, where the land is taken by condemnation, will be its value to him for the special use to which he is so restricted. Thus, In re Albany Street in New York City, Ir Wendell, page I49, the ground taken for a street was a cemetery, and it appeared that it could not be used for any other purpose by the corporation of Trinity Church than for burying the dead. It was there held that it was the damage sustained by the church which the commissioners were to ascertain, and that the true rule of determining such damage was to appraise the property at its then present vaiue to the owner, considering the extent of his interest and the qualified rights which might be exercised over it. To the same effect is Stebbins $v$. Metropolitan Board of Works, 6 Q. B., page 37, where'a part of a graveyard was condemned for a street and where the owner held it subject to a restriction'which it was not practically possible for him to remove." " And a nominal award in this last case was upheld, although the land taken became of immense value as soon as title was vested in the public relieved of the restriction. 9

It is frequently the case that a piece of land taken for street purposes is encumbered by easements of right-of-way created by private contract. The Court of Appeals has held ${ }^{10}$ that the owner of the naked fee of a strip of land encumbered by easements which permit the abutting owners to use the strip for street purposes, where such owner of the fee is not an abutting owner, is entitled to only a nominal award for his interest in such strip of land. But in another leading case ${ }^{11}$ where a municipality sought to condemn the fee in the bed of an existing street owned by the abutting owners it was held that the ownership of the fee of the land in a street by an abutting owner vests him with the right to defend against and enjoin a user for an encroachment upon the street by any legislative or municipal authority for purposes inconsistent with those uses to which streets should be or have ordinarily been subjected, unless provision for just compensation is made; and that where this fee is taken by legislative

8119 Illinois, page 529 (Railroad Company $v$. Catholic Bishop).

9 See also B. R. \& M. R. R. Co. v. Barnard, 9 Hun. 104.

10 Matter of Adams, I4I N. Y. page 297.

11 City of Buffalo v. Pratt, I3I N. Y. 293. 
authority, the owner is entitled not merely to nominal damages, but to such substantial damages as may be ascertained by measuring the effect upon the value of his remaining property of the loss of the fee of the street. It is to be noted that the ineasure of damage in this case is the depreciation in value of the abutting property which is not taken by reason of the taking of the fee in an existing street, and that the damage is not at all to be measured by what might be the value of the land in this street, if it were not a street, but freed from street easements.

Again in the Matter of One Hundred and Sixteenth Street ${ }^{12}$ the court unanimously concurred in Judge Ingraham's opinion, which states that the commissioners cannot properly award damages to an owner of an easement of right-of-way and use for street purposes over a strip of land taken for a street, the reason being that his easement is not taken and destroyed, and that he therefore is not damaged. Judge Ingraham, in his opinion, said:

"The New York Hospital was the owner of the fee of the land taken, and was entitled to be paid its value in this proceeding. * * * It is the property owned by the New York Hospital that is to be valued, and if such property is subject to any easement either in favor of the public or of an individual the award should be for the value of the property subject to such easement, as such. easement is not in this proceeding taken or appropriated."

The principle upon which all these cases seem to rest is that the owner is entitled to compensation only for the market value of his holding in its encumbered or restricted condition, and where nothing of value is taken or destroyed, no damages are recoverable.

Experts seem to differ in their opinions as to the value of similarly situated lots of different depths. When they were accustomed to apply the Hoffman rule they were obliged, in order to be consistent, to express the opinion that a lot 25 feet front and roo feet deep was worth less per square foot than a lot similarly situated 25 feet front and only 75 feet deep, and that a lot I25 feet in depth was worth still less per square foot, and that, generally speaking, the deeper a lot was the less valuable was it per square foot, and that the shallower it was the greater value did it have per square foot.

Notwithstanding the general agreement of experts on this rule I was led to investigate the matter as a fact. I considered

12 I App. Div. Rep. 436. 
that auction sales of lots lying next to each other, where the rear line of the tract was not parallel to the front line, and where, in consequence, the lots were of different depths, made on the same day, under the same conditions, to different vendees, would furnish a fair criterion. In every case that $I$ in vestigated $I$ found that where the difference in the depths of the parcels varied from 40 to 125 feet, the parcels sold for very nearly the same price per square foot whether they were shallow parcels or deep parcels, the variation in the price per square foot being only the usual variation observed at every auction sale where lots similarly situated and lying next to each other are sold to different vendees; and that no rule could be deduced from these sales showing that shallow lots were more valuable per square foot than deep lots. Of course the location and the uses to which the property could most profitably be put would have a great deal to do with the depth which a parcel might have without a proportional decrease in its value per square foot.

.Some experts who formerly testified according to the Hoffman rule, and persisted in asserting that a lot 25 feet front and 25 feet in depth was worth more per square foot than a lot 50 , 75 or roo feet in depth, of the same frontage, now that they have stopped using that rule, maintain that a lot less than 75 feet in depth on a residence street is of less value per square foot than a lot of the same frontage and between 75 and 125 feet in depth. Others maintain that until a lot has been reduced to a depth less than 50 feet, it does not by reason of its reduced size become of less proportional value. Others again hold that a lot 125 feet in depth does not get a proportional increase in value over what it would be worth if it were only roo feet in depth.

These are questions which must be taken up and considered in each particular case.

Where there are improvements on the land it is a favorite contention that the measure of damages is the market value of the owner's title to the bare land without improvements, plus the cost of the improvements, less the depreciation in the value of the improvements by reason of deterioration. There is no authority for proving damages in this way except that this method has often been pursued by commissions. Of course, under some circumstances, this method does not lead to a different result than would be arrived at if the strictly legal method of presenting proof were pursued. For instance, if the improvements on a lot, the whole of which is taken, add to the market value of the real estate the full cost of the improvements, the 
market value of the entire real estate would be the value of the owner's interest in the land unimproved, plus the cost of the improvements. But in very many cases the market value of the real estate is much less than the value of the property if vacant, plus the cost of the buildings and other improvements, less deterioration by reason of wear and tear and the elements. Particularly is this frequently the case in the upper part of the city where pieces of land have erections on them that were put up for an entirely different use than that for which a reasonable -man would use the property at the present time. For instance, near Casanova Station on Hunt's Point, the so-called Whitlock Mansion was, before the war, erected at an expense of $\$ 300,000$, but this same mansion, with ninety acres of land, was sold for something like $\$ 80,000$ only a few years ago. Then there may have occurred after the erection of the improvements some change in the surroundings which seriously affects their value. For instance, the grade of One Hundred and Forty-ninth street, near the Harlem Railroad tracks, was changed, and the owners of the buildings fronting on the street recovered thousands of dollars as damages from the city; but when One Hundred and Forty-ninth street was subsequently widened the builders called to testify as to the value or cost of reproduction of these same buildings, for which damages on account of the change of grade had already been awarded, made no allowance for such damages but gave the cost of reproduction as the value of these buildings, regardless of the injury done them by the change of grade. Of course, less conspicuous examples of the truth of the general proposition that the cost of its construction, or the cost of reproducing a building, has nothing to do with its market value, will readily occur to every one.

An important reason why testimony should not be offered in this way is that it does not give counsel an opportunity to crossexamine witnesses. The real estate expert is called to testify to the value of the land alone, and can be cross-examined upon that. The builder is called to testify as to the cost of reproducing the improvements, or, as it is sometimes expressed, the value of the improvements separate from the land. The builder can only be cross-examined as to the quantity of material he thinks is necessary for the construction of such a building and the price of the materials and labor involved. He knows nothing of the value of the building as it exists on a definite parcel of land and taken in connection with it, and is not offered as a real estate expert. There has, therefore, been no testimony offered as to 
the market value of the whole property as it stands before condemnation. It is only by an inference, and that, too, an inference that is not a proper one to draw, that the commissioners can deduce from the testimony offered the amount to which the owner is entitled as his damages, and counsel is not afforded any opportunity to cross-examine witnesses on the real question which it is competent for the commissioners to investigate. This is a very serious matter, particularly so where the commissioners are laymen and not familiar with the legal measure of damages.

The attempt, therefore, to prove the value of improved property in this way is as improper as it is unwarranted by any authority. To pursue this method is to treat the building as personalty, as separated from and not as part of the land, for obviously the builder is testifying to what would be the value of the building placed on the most advantageous site for a building of its kind and character. It is not proper to consider the building as separated from the land. The statutes authorizing street opening proceedings contemplate the taking of real estate only, and the city cannot condemn personal property. ${ }^{13}$ The investigation must be confined strictly to the value of the real estate, the owner's estate in the land including the improvements.

Of course a builder's testimony may be proper if a proper foundation is laid for it. If, for instance, a real estate expert states on cross-examination that he based his opinion on what a builder had told him as to the cost of reproducing the building, it might be deemed proper to offer a builder's testimony to show that the witness was wrongly informed.

In a railroad case ${ }^{14}$ the court says: "The cost of structures put upon the land was not competent, and such evidence was properly rejected. The value of the land and structures thereon was alone to be determined; the cost is not a rule of damages."

In the Matter of Opening One Hundred and Thirty-ninth street, on the motion to confirm the report, O'Brien, J., said: "Objections are made to the confirmation of the report of the Commissioners, as follows:

"First-That the Commissioners failed to make any award for the fruit trees of Mrs. Riddock.

"T.he trees are a part of the freehold and should be valued as such. There was no error on the part of the Commissioners in failing to make a specific award for the trees."

18 In the Matter of N. Y. C. \& H. R. R.R. Co., 36 Hun. 306.

14 Matter of the N. Y., W. S. \& B. Ry. Co., 37 Hun. 318 . 
In Evans v. Keystone Gas Company ${ }^{15}$ Gray, J., in his opinion, said: "This action was brought to recover damages of the defendant for the injury caused to shade trees belonging to the plaintiff, by the escape of natural gas from a main or pipe laid along the street bounding his premises. *** The witness was asked to state the value of the trees in question. ** * The argument now is that the evidence was incompetent on the question of the damage. That is true, and the rule in such a case as this is the difference between the value of the land before and after the injury."

In a recently reported case ${ }^{16}$ a railroad proposed to cut through a farm, leaving 46 acres on one side of its tracks and 167 acres on the other side. One of the witnesses said on re-direct examination, that he made up the $\$ 9,000$ of depreciation to which he had testified as follows: "I have several items: First, the loss in the quantity of production I put at sixty dollars; on account of the drainage, etc., I think sixty dollars per year. I put twelve hundred dollars on interest at five per cent to produce that amount. The driving and crossing with stock I put at fifty cents per day, amounting to one hundred and eighty-two dollars and fifty cents for one year; for all time, three thousand six hundred and fifty dollars. I find another element, the crossing and re-crossing with teams to work the land on the south side. Third-I put the last item at one thousand three hundred and sixty dollars. Fourth-From fire there is some damage; I put that at sixty-two dollars per year, and for all time, twelve hundred and forty dollars."

In this case the award was reversed on the ground that "the opinion of the witness should have been limited to the market value of the farm after the completion of the road, taking into consideration all the incidental injuries to the remaining lands, if any."

It is often attempted to prove damages in street openings in the same way.

Another way of applying the same theory is to divide a parcel of land into lots and to claim damages for each individual lot, the result being to largely increase the apparent damages.

'The correctness of this method is very frequently seriously argued. But as Judge Learned in a railroad condemnation case said:17 "It is very plain that to make a map of a tract of land

15 I48 N. Y. II 2.

16 Matter of N. Y., W. S. \& B. Ry. Co., 29 Hun. 609.

17 Matter of N. Y., L. \& W. R. R. Co., 27 Hun. I5I. 
and lay out streets thereon does not add in the least to its value, any more than it would to mark out churches and school-houses on the lots themselves."

It is often suggested to commissioners by claimants that because the owner of the fee has carved out of it a leasehold estate, the sum of the damages to the tenant and the landlord amounts to more than the full value of the property. The authorities, however, are clear that full payment at the market value answers the constitutional provision regarding a just compensation to be paid to the owners, and that, when payment has been made for all that the property is worth, nothing more can be demanded. The value of the leasehold is to be carved out of the full award for the damage to which the owner in fee would be entitled if he had not parted with an interest in the property. ${ }^{18}$

The above are only a few of the many ways in which it has been sought to apply a general rule of damage, which sounds plain enough when stated, but still gives opportunity for much ingenious theorizing. Some of them, like the application of the Hoffman rule, have been successfully urged upon commissioners and have gone unchallenged for years. Others are coming up now for the first time. In most of the cases the foundation for the inequitable claim is some statute. Concerning street openings in New York City it is particularly true, what is, in general, true of all branches of the law, that legislation is enacted with too little intelligent consideration and with too great facility. Each year's flood of new statutes creates new uncertainties and renders more difficult the task of him who seeks to know the law.

\section{Henry deForest Baldwin.}

18 In the Matter of the N. Y., W. S. \& Buffalo R. R., 35 Hun. 633; Matter of Newton, 45 State Reporter I8; Matter of Dept. of Pub. Parks, 53 Hun. 280-298. 